\title{
Bullinger as selfstandige en onafhanklike teoloog uitgelig
}

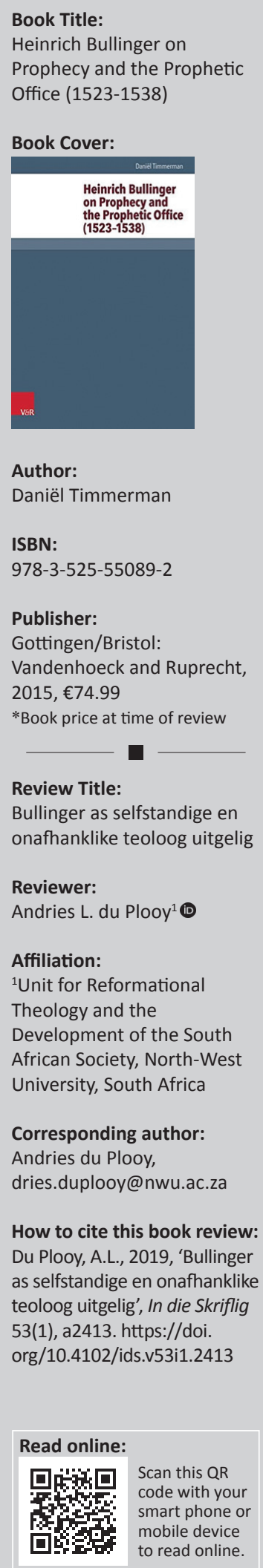

Die publikasie het as proefskrif gedien onder die promotorskap van prof. Herman Selderhuis, verbonde aan die Teologiese Universiteit van Apeldoorn, Nederland. Die mede-promotor was dr Andreas Muhling. Die doel van hierdie publikasie is kortliks die volgende:

- Die besondere klem wat Bullinger in sy werke op die konsepte profeet en profesie gelê het.

- Die fokus op profesie is verder gemotiveer deur die navorsing daaroor in die tyd van die Switserse reformasie, byvoorbeeld oor die teologie van Bullinger se voorganger in Zürich, naamlik Zwingli.

- Die fokus op die profetiese verklaring van die Skrif was ook sterk aan die orde tydens die sestiende-eeuse Reformasie in lande soos Frankryk, Engeland en Duitsland. Dit verskaf die konteks waarbinne Bullinger se teologie daaroor verder begryp kan word.

- Die skrywer wou ook Bullinger se standpunte oor die profetiese amp belig en aksentueer.

- Laastens word die geskiedenis van die Zürich se Instituut vir die Studie van die Skrifte, bekend as die 'Prophezei', belig en geëvalueer.

Die periode wat behandel word, is die tydperk 1523-1538, 'n besondere tyd in die geskiedenis van die Reformasie waarin nie net figure soos Zwingli (vroeër) en Bullinger aktief werksaam was nie, maar waarin ook Luther, Calvyn, Oecolampadius en andere uitstaande teologiese bydraes gelewer het.

Die indeling van die behandeling van die inhoud word soos volg saamgevat:

- Profete en profesie binne die Christelike tradisie: Hier val die klem op die profete en profesie vanaf die Nuwe-Testamentiese tyd en daarna tot by die sestiende-eeuse Reformasie, asook op die diens van profesie in die kerk en die profeteskap van alle gelowiges. Hier word ook aangedui hoe profete as verkondigers en verklaarders van die Skrif werksaam was.

- Profete in die konteks van Zürich: In hierdie deel word aandag gegee aan Zwingli, asook aan die opkoms van die Anabaptisme.

- Daarna kom besondere werke van Bullinger aan die orde: eerstens, De prophetae libri duo van 1525; tweedens, De prophetae officio van 1532; en derdens, De episcoporum institutione et functione van 1538.

- Laastens handel dit oor Bullinger en die sogenaamde 'Prophezei'.

'n Besondere aspek wat deurgaans na vore kom, is die klem op die gesag in die kerk. In reaksie teen die Rooms-Katolisisme waar die gesag veral in die pous en op die kerklike strukture geplaas is, is die korrektief gebring, naamlik dat dit in die profesie eintlik alleen oor solus Christus audiendus [luister na Christus alleen] gaan.

Ook teenoor die Anababtiste waar hoofsaaklik op grond van tekste oor die Heilige Gees en in besonder 1 Korintiërs 14: 29-31 aanvaar is dat elke gelowige deur die Gees gelei word om finaal te bepaal wat as gesagvol beskou kan word en van predikers aanvaar moet word, is die korrektief gebring, naamlik dat die Skrif alleen gesagvol is. Profete en verklaarders van die Skrif word deur die Gees verlig om as dienaars (binne die amp) die Woord van God te verklaar en toe te pas. En steeds kan en behoort gelowiges hierdie werk van die profete te toets.

Die klem wat geplaas is op die kuns of manier waarop die Woord van God deur die profete (ampsdraers), soos apostels (voorheen), en predikers (tans) gepreek of aangebied moet word, is ook interessant. ' $n$ Ware profeet is deur God geroep en begenadig om die Woord te verkondig. In Latyn is die beskrywing soos volg gegee: 'a true prophet must have "docendi officium" and "dicendi artificium"' (p. 171). Met ander woorde, die amp om as profeet op te tree, asook die kuns of vermoë om die Woord te verkondig, is hier ter sprake. 
Die besondere rigtinggewende teks waarop klem gelê word om die werk van 'n profeet te begryp, is 1 Korintiërs 14:3, naamlik om op te bou, te vermaan of te bemoedig en te vertroos.

Dis opvallend dat Bullinger eerstens feitlik alle soorte dienste wat te doen het met verkondiging as profetering ag, en tweedens, dat hy Christus nie as profeet beskou nie. Hy praat van Christus se munus duplex en nie van die munus triplex nie.

Die skrywer kom tot die gevolgtrekking dat Bullinger se standpunte oor die begrippe profeet en profesie nóg nuut nóg oorspronklik is. Hy sluit aan by die Christelike tradisie soos dit by hom bekend was, asook by die sienings van sy tydgenote. Veral sy voorganger, Zwingli, asook Erasmus en Luther het 'n invloed op sy denke en geskrifte gehad. Bullinger se bydrae, volgens die skrywer, lê dan veral in sy didaktiese en historiografiese benadering tot die onderwerp. Bullinger kan as 'n selfstandige en onafhanklike teoloog beskou word, hoofsaaklik vanweë sy besondere historiese benadering en kennis van die ou Christelike bronne.

Die publikasie getuig van deeglike navorsing en goeie kennis van veral die sestiende-eeuse Reformasie en Reformatore. Die gebruikmaking van oorspronklike bronne sowel as van ander navorsing oor bepaalde aspekte van die inhoud, verhoog die standaard en betekenis van die publikasie.

Dit sou na my oordeel wel waarde kon toevoeg indien die skrywer op 'n uitvoerige(r) wyse aandag gegee het aan 'n kritiese evaluering van Bullinger se standpunte oor die onderwerp in die lig van wat in die Woord van God daaroor geopenbaar word.

Vir enige teoloog, maar veral vir teoloë binne die reformatoriese tradisie is die boek ' $n$ waardevolle toevoeging tot ons kennis van die sestiende-eeuse Reformasie en oor die diens van die profeet. Dit is veral waardevol in ons tyd waar die fokus op die gebeure vanaf 1517 tot 1618 en 1619 val. 